Acta vet. scand. $1978,19,73-83$.

From the Department of Animal Hygiene, College of Veterinary

Medicine, Helsinki, Finland.

\title{
DEHYDRATED MINK MANURE AS A PROTEIN SOURCE FOR GROWING PIGS
}

\author{
By \\ Matti Näsi ${ }^{\star}$, Hannu Saloniemi and Kaarlo Kallela
}

\begin{abstract}
NÄSI, M., H. SALONIEMI and K. KALLELA: Dehydrated mink manure as a protein source for growing pigs. Acta vet. scand. 1978, 19, 73-83. - The use of dehydrated mink manure as a protein source for growing pigs was studied by substituting 7.5 and $15 \%$ $(\mathrm{w} / \mathrm{w})$ of the complete feed with manure and a corresponding amount of barley. The manure used had a poor feed value as compared to the values obtained earlier in digestibility tests in minks. The crude protein content was $21.3 \%$. The addition of mink manure to the feed did not adversely affect the feed consumption, nor were any effects on the health of the pigs observed. The differences in daily gain and feed efficiency recorded between the experimental groups were not statistically significant. The number of experimental animals was small, and a large variation occurred within the groups. The addition of mink manure to the diet resulted in lower weight gain, apparently due to a lower energy supply. The groups given mink manure received less feed units than the controls. No harmful effects of the manure feeding on carcase quality was observed and organoleptic tests revealed no changes in the smell or taste of the meat. No changes were found in the digestive tracts, livers or kidneys of the pigs.
\end{abstract}

mink manure; pig; waste utilization; protein s o u r ce.

Fur-ranching is a significant industry in Finland. In 1976, 3.2 millions of mink furs were produced, which accounted for some $14 \%$ of the world production. In all, there are 3100 ranches, most of which are enterprises managed in connection with agriculture. Ranching is chiefly concentrated to the coastal area, where fish is available for fodder. On small ranches the mink manure is easily disposed of as soil fertilizer. Regionally,

* Present address: The Department of Animal Husbandry, University of Helsinki, Finland. 
though, difficulties with handling manure occur on large ranches which do not possess large enough fields. On such ranches storing and handling of the manure may bring about environmental disturbance. Mink manure contains 3 to 5 times more nutrients than that coming from piggeries and cowsheds (Loehr 1974, Anon. 1975).

The total amount of fodder used annually in mink ranching is approx. 250 million $\mathrm{kg}$. The main part of this is fish and abattoir offals. For the production of 1 mink skin, $60 \mathrm{~kg}$ of fodder is required. Of the $18 \mathrm{~kg}$ dry matter consumed by $1 \mathrm{mink}$, only $750 \mathrm{~g}$ remains in the organism. In the droppings and urine $17 \mathrm{~kg}$ of dry matter is eliminated, which is equivalent to $52 \mathrm{~kg}$ fresh manure.

By feeding and digestibility experiments, mink manure has been demonstrated to have a very high content of crude protein. Under ordinary feeding conditions the crude protein content equals some $30-50 \%$ of the manure dry matter. In some manure samples the crude protein has exceeded $60 \%$ of the dry matter. The high crude protein content of the manure is owing to the high protein content of mink fodder. Judging from the analyses, mink manure potentially represents a significant source of protein, the utilization of which is worth investigating.

The need of protein for the feeding of single stomached animals has strongly risen during later years. The domestic production of grain for feed is sufficient for the supply of energy. Its protein content and amino acid composition, however, do not suffice to fill the requirements of fast growing pigs and their thin fat carcase without supplementary protein (Madsen 1975). Protein feeds of domestic origin to a favourable price are scanty. Because of this, the production of pork is greatly dependent on imported fish meal and soya and their price levels. The developing of the domestic protein production and the search for new protein sources have been the object of an intensive research during the latest few years (Committee Report 1974).

The purpose of this investigation was to study the possibilities of utilizing dehydrated mink manure as a protein supplement to pigs and its effect upon their health, metabolism and carcase quality. There are no previous experiences of feeding mink manure to pigs, but investigations on pig and poultry manure have been made (Diggs et al. 1965, Perez-Aleman et al. 1971, Harmon 1974, Harmon \& Day 1974). 


\section{MATERIAL AND METHODS Experimental conditions}

Growing pigs were subjected to 2 feeding experiments, where part of the protein was substituted by dehydrated mink manure. A total number of 36 growing pigs of Yorkshire and Landrace breeds (18 females and 18 castrated males) served as experimental animals. They were taken into the experiment at an age of 8 weeks, weighing $20 \mathrm{~kg}$. The animals were divided into 3 groups as equal as possible as to sex, growth, weight and breed. They were penned in groups of 6, each feeding group in its own pen.

The growth of the pigs was followed up by weekly weighings. They were sent to slaughter at a live weight of $88 \mathrm{~kg}$. The carcase quality was assessed subsequent to slaughter and cutting, according to Uusisalmi (1969).

Besides routine meat inspection, the digestive tract and other viscera were examined. Tissue samples were taken for histological examination from the livers and kidneys. Each carcase was subjected to both boiling test and taste assessment.

\section{Feeds and feeding}

A regular commercial complete feed for growing pigs was used as a control. Complete feed I (18\% crude protein) was used up to $40 \mathrm{~kg}$ live weight, and complete feed II (16\% crude protein) between 40 and $90 \mathrm{~kg}$. In the ration to Group II, $7.5 \%$ of the complete feed was substituted with barley and $7.5 \%$ with dehydrated mink manure. Group III received a ration consisting of $70 \%$ complete feed, $15 \%$ barley and $15 \%$ mink manure.

The mink manure was collected from under the pens at the Helve experimental ranch. When collecting, a slight mixing of straw and soil with the manure could not be avoided. For the first experiment the manure was dehydrated in a laboratory drying closet and for the second one in a drum dryer.

Feeding levels (Table 1) were determined according to the high-low standards (Partanen 1970). One week was allowed for the change-over to the experimental diets. The feed was given dry in throughs, twice daily. Water was given by automats ad lib.

The mean composition and feed values of the experimental feeds are presented in Table 2. The chemical composition of the mink manure is given in Table 3. 
T a b l e 1. Feeding scheme for the groups.

\begin{tabular}{|c|c|c|c|c|c|c|c|c|}
\hline \multirow[b]{2}{*}{$\begin{array}{c}\text { Weeks } \\
\text { from } 20 \mathrm{~kg} \\
\text { live } \\
\text { weight }\end{array}$} & \multirow[b]{2}{*}{$\begin{array}{c}\text { Live } \\
\text { weight } \\
(\mathrm{kg})\end{array}$} & \multirow{2}{*}{$\begin{array}{c}\text { Group I } \\
\text { (control) } \\
\text { complete } \\
\text { feed } \\
(\mathrm{kg})\end{array}$} & \multicolumn{3}{|c|}{ Group II } & \multicolumn{3}{|c|}{ Group III } \\
\hline & & & $\begin{array}{c}\text { complete } \\
\text { feed } \\
(\mathbf{k g})\end{array}$ & $\begin{array}{c}\text { barley } \\
(\mathbf{k g})\end{array}$ & $\underset{(\mathrm{kg})}{\operatorname{mink}}$ & $\begin{array}{c}\text { complete } \\
\text { feed } \\
(\mathbf{k g})\end{array}$ & $\begin{array}{c}\text { barley } \\
\text { (kg) }\end{array}$ & $\underset{(\mathbf{k g})}{\operatorname{mink}}$ \\
\hline 1 & 20 & 1.20 & 1.02 & 0.09 & 0.09 & 0.83 & 0.18 & 0.18 \\
\hline 2 & 25 & 1.30 & 1.10 & 0.10 & 0.10 & 0.90 & 0.20 & 0.20 \\
\hline 3 & 30 & 1.50 & 1.27 & 0.11 & 0.11 & 1.03 & 0.23 & 0.23 \\
\hline 4 & 35 & 1.65 & 1.40 & 0.12 & 0.12 & 1.15 & 0.25 & 0.25 \\
\hline 5 & 40 & 1.85 & 1.57 & 0.14 & 0.14 & 1.28 & 0.28 & 0.28 \\
\hline 6 & 45 & 2.05 & 1.75 & 0.15 & 0.15 & 1.45 & 0.30 & 0.30 \\
\hline 7 & 50 & 2.25 & 1.92 & 0.17 & 0.17 & 1.58 & 0.33 & 0.33 \\
\hline 8 & 55 & 2.45 & 2.08 & 0.18 & 0.18 & 1.72 & 0.37 & 0.37 \\
\hline 9 & 60 & 2.60 & 2.20 & 0.20 & 0.20 & 1.80 & 0.40 & 0.40 \\
\hline
\end{tabular}

Table 2. Average chemical composition of feeds (1 feed unit = $0.7 \mathrm{~kg}$ starch equivalent).

\begin{tabular}{|c|c|c|c|c|c|c|c|c|c|}
\hline \multirow[b]{2}{*}{ Foods } & \multirow[b]{2}{*}{$\begin{array}{c}\text { Experi- } \\
\text { ment }\end{array}$} & \multirow[b]{2}{*}{$\begin{array}{c}\text { Dry } \\
\text { matter }\end{array}$} & \multicolumn{5}{|c|}{ Percentage in dry matter } & \multirow{2}{*}{$\begin{array}{c}\text { Energy } \\
\text { content } \\
\text { f.u./ } \\
\text { kg feed }\end{array}$} & \multirow{2}{*}{$\begin{array}{c}\text { Digestibl } \\
\text { crude } \\
\text { protein } \\
\text { g/f.u. }\end{array}$} \\
\hline & & & $\begin{array}{l}\text { crude } \\
\text { protein }\end{array}$ & $\begin{array}{l}\text { ether } \\
\text { extract }\end{array}$ & $\begin{array}{l}\text { crude } \\
\text { fibre }\end{array}$ & $\begin{array}{l}\text { nitrogen } \\
\text { free ext. }\end{array}$ & ash & & \\
\hline Complete feed I & 1 & 90.0 & 20.2 & 2.8 & 3.7 & 68.3 & 5.0 & 0.99 & 145 \\
\hline Complete feed I & 2 & 90.1 & 19.5 & 3.4 & 4.4 & 66.7 & 4.4 & 0.98 & 141 \\
\hline Complete feed II & 1 & 89.4 & 18.0 & 2.8 & 4.0 & 70.4 & 4.8 & 0.99 & 129 \\
\hline Complete feed II & 2 & 89.3 & 18.2 & 3.6 & 5.1 & 67.4 & 5.8 & 0.98 & 132 \\
\hline Barley & 1 & 89.1 & 15.3 & 1.9 & 4.8 & 75.7 & 2.4 & 1.00 & 107 \\
\hline Barley & 2 & 89.3 & 12.8 & 2.0 & 4.1 & 78.8 & 2.3 & 1.02 & 89 \\
\hline Mink manure & 1 & 96.6 & 21.7 & 5.4 & 11.4 & 26.0 & 35.6 & 0.43 & 325 \\
\hline Mink manure & 2 & 98.0 & 21.0 & 12.1 & 12.6 & 40.4 & 34.0 & 0.48 & 286 \\
\hline
\end{tabular}

\section{Health of experimental animals}

Between feeding groups no differences occurred concerning the palatability of feeds. During Experiment 1, all pigs suffered diarrhea for about 1 week. The condition emanated from another group of experimental pigs housed in the same part of the piggery. During this period all the pigs left some of their feed unconsumed. Otherwise the pigs remained healthy throughout the experiments. 
Table 3. Chemical composition of mink manure (dry matter).

\begin{tabular}{lrrllr}
\hline & & $\mathrm{m} \pm \mathrm{s}$ & & & $\mathrm{m} \pm \mathrm{s}$ \\
\hline Crude protein & $\%$ & $21.3 \pm 1.0$ & Alanine & $\mathrm{g} / \mathrm{kg}$ & $13.4 \pm 4.6$ \\
Crude fat & $\%$ & $8.7 \pm 3.8$ & Arginine & $\mathrm{g} / \mathrm{kg}$ & $5.3 \pm 5.0$ \\
Crude fibre & $\%$ & $12.0 \pm 0.7$ & Aspartic acid & $\mathrm{g} / \mathrm{kg}$ & $11.6 \pm 1.0$ \\
N-free extract & $\%$ & $23.3 \pm 3.2$ & Cystine & $\mathrm{g} / \mathrm{kg}$ & $1.2 \pm 0.5$ \\
Ash & $\%$ & $34.8 \pm 2.3$ & Glutamic acid & $\mathrm{g} / \mathrm{kg}$ & $15.9 \pm 0.6$ \\
Calcium & $\mathrm{g} / \mathrm{kg}$ & $\mathbf{1 6 . 1} \pm 1.9$ & Glycine & $\mathrm{g} / \mathrm{kg}$ & $13.0 \pm 0.8$ \\
Phosphorus & $\mathrm{g} / \mathrm{kg}$ & $\mathbf{3 2 . 7} \pm 4.3$ & Histidine & $\mathrm{g} / \mathrm{kg}$ & $2.0 \pm 0.3$ \\
Magnesium & $\mathrm{g} / \mathrm{kg}$ & $5.6 \pm 1.2$ & Isoleucine & $\mathrm{g} / \mathrm{kg}$ & $4.0 \pm 0.5$ \\
Sodium & $\mathrm{g} / \mathrm{kg}$ & $5.2 \pm 0.4$ & Leucine & $\mathrm{g} / \mathrm{kg}$ & $6.5 \pm 0.9$ \\
Potassium & $\mathrm{g} / \mathrm{kg}$ & $\mathbf{8 . 8} \pm 0.7$ & Lysine & $\mathrm{g} / \mathrm{kg}$ & $5.3 \pm 1.4$ \\
Iron & $\mathrm{mg} / \mathrm{kg}$ & $\mathbf{8 8 6} \pm 37$ & Methionine & $\mathrm{g} / \mathrm{kg}$ & $1.7 \pm 0.4$ \\
Copper & $\mathrm{mg} / \mathrm{kg}$ & $37 \pm 8$ & Phenylalanine & $\mathrm{g} / \mathrm{kg}$ & $3.7 \pm 0.6$ \\
Manganese & $\mathrm{mg} / \mathrm{kg}$ & $203 \pm 62$ & Proline & $\mathrm{g} / \mathrm{kg}$ & $9.5 \pm 0.4$ \\
Zinc & $\mathrm{mg} / \mathrm{kg}$ & $577 \pm 119$ & Serine & $\mathrm{g} / \mathrm{kg}$ & $6.1 \pm 0.8$ \\
& & & Threonine & $\mathrm{g} / \mathrm{kg}$ & $5.8 \pm 0.3$ \\
& & & Tyrosine & $\mathrm{g} / \mathrm{kg}$ & $3.1 \pm 0.2$ \\
& & & Valine & $\mathrm{g} / \mathrm{kg}$ & $5.7 \pm 0.7$ \\
\hline
\end{tabular}

\section{RESULTS AND DISCUSSION}

The mink manure used was nutritionally poorer than could be expected on the basis of previous composition data. The average crude protein content was only $21.3 \%$. Of this $53 \%$ consisted of amino acids. The content of essential amino acids was higher than in chicken manure (Näsi 1976). The low protein content is obviously caused by microbial disintegration of the manure during storage and losses occurring during dehydration. The dehydration may also have lowered the quality of the protein. The ash content of the mink manure was high $(34.8 \%)$, while in digestibility tests it has been found to be less than $10 \%$. Of the ash, $27.4 \%$ was insoluble in HCl. When collecting, soil and sand had come into the manure. The crude fibre content was $12 \%$, of which the main part came from litter mixing with the manure under the pens, which could not be completely avoided when collecting the manure. Mink manure meant for feed should be collected from a firm surface in order to avoid contamination with impurities which may lower the feed value. The collecting should be done frequently enough to avoid protein losses due to microbial fermentation.

The results concerning the growth of the pigs and their feed 


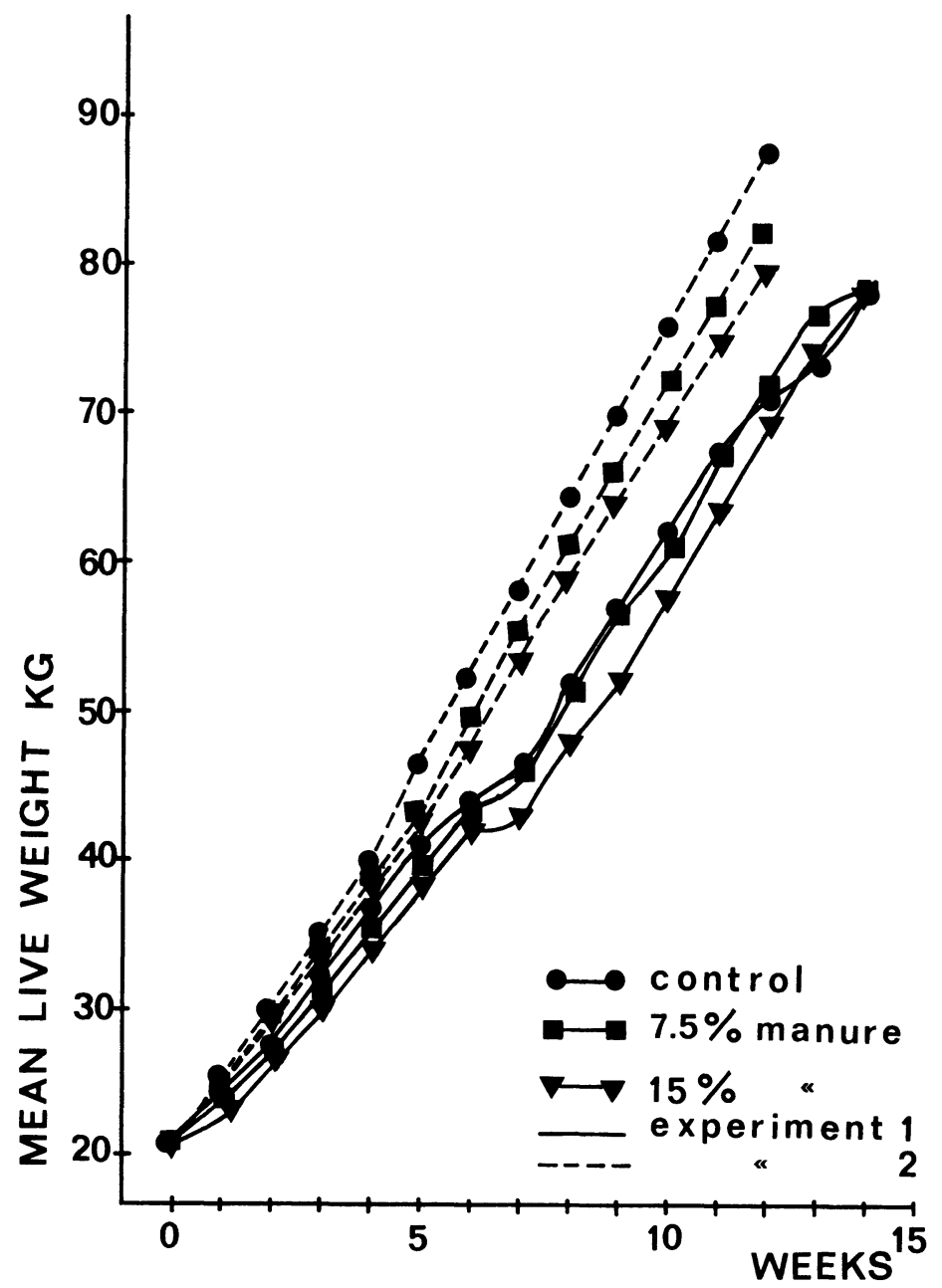

Figure 1. Live weight of pigs receiving different amounts of dried mink manure.

consumption are shown in Table 4. In Fig. 1, the weight development of each experimental group until the first pigs were sent to slaughter are shown. In Experiment 1, the weight gains within the different groups remained low, an average of 586-637 g daily. The pigs receiving mink manure grew slightly better than the controls. The poor gains may partly depend on insufficient ventilation during the exceptionally hot summer. The diarrhea of course also had some effect. 


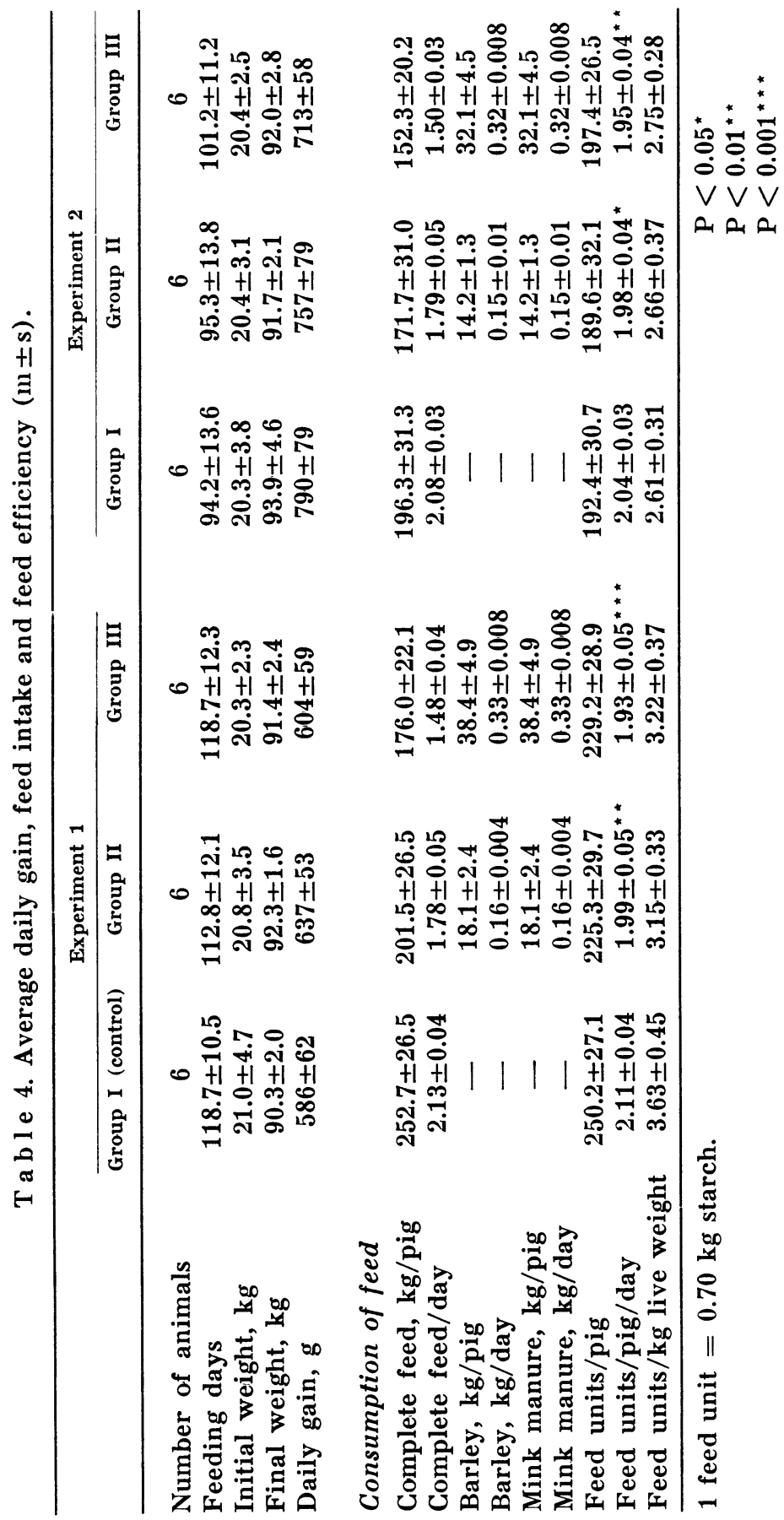


In Experiment 2, the pigs gained weight rather well. The groups receiving mink manure showed $4-10 \%$ poorer gains than the controls. The experimental groups consisted of only 6 animals each and variation within the groups was large. The differences in weight gain were not statistically significant. Because of the low energy value of the mink manure, the groups who received it got less feed units per day than the controls. The differences were proved statistically significant. In Experiment 1 , the utilization of feed was $11-13 \%$ better in the groups receiving mink manure and 2-5\% poorer in Experiment 2, as compared to the controls. The differences, though, were not statistically significant. In Experiment 2, the utilization of feed was highly efficient $(2.61-2.75$ f.u. $/ \mathrm{kg}$ weight gain $)$. The results of carcase examinations are shown in Table 5. Small differences in carcase quality occurred. The differences were not consequent or significant, except for meat color in Experiment 1. Boiling tests revealed no abnormal odor in the meat of the pigs fed mink manure. The taste and smell of the meat were also normal. Meat inspection and examination of the digestive tracts of the pigs revealed no significant changes. No abnormal changes were observed by histological examination of liver and kidney tissue.

Because of the small number of animals used for the experiments, it is difficult to draw any direct conclusions regarding the value of mink manure as a source of protein. Besides, the feed value of the mink manure used for the experiments was poor. The experiments revealed, however, no harmful effects of mink manure neither on the health of the animals nor on carcase or meat quality. These observations are consistent with the good growth of the pigs and efficient feed utilization. The amount of mink manure used should, however, be restricted to $10 \%$, because otherwise the energy content of the feed becomes too low. The recommended level of chicken or pig manure in feeds is 10-15\% (Diggs et al. 1965, Perez-Aleman et al. 1971, Eggum \& Christensen 1973). In order to determine the digestibility of mink manure and its biological value, further investigations are required. Feeding experiments should be performed with large numbers of animals in order to increase the reliability of the results. The technical difficulties connected with collecting, storage and dehydrating mink manure require research as well. 


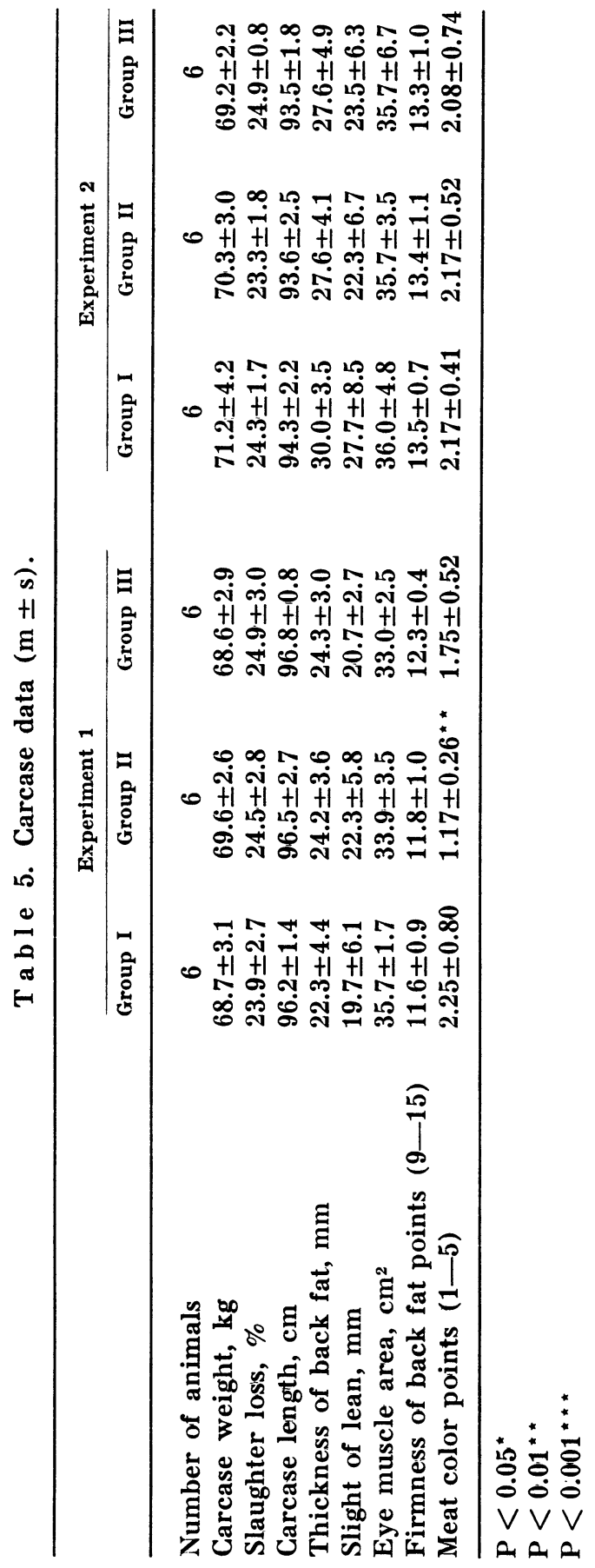




\section{REFERENGES}

Anon: Hvilke værdier ligger der i minkg $\varnothing$ dning. (Value of mink manure). Dansk pelsdyravl 1975, 38, 142.

Committee report: Valkuaisrehutoimikunnan mietintö II. (Committee report on protein feeds). 1974, 137, 1-115, Helsinki.

Diggs, B. G., B. Baker Jr. \& F. G. James: Value of pig feces in swine finishing rations. J. Anim. Sci. 1965, 24, 291.

Eggum, B. O. \& K. D. Christensen: T $\varnothing$ rret griseg $\varnothing$ dning anvendt til foder. (Dried pig manure as feed). Ugeskr. agron. horton. 1973, 2, 97-120.

Harmon, B. G.: Potential for recycling swine waste. Feedstuffs 1974. $46,9,40-42$.

Harmon, B. G. \& D. L. Day: Nutritive value of amino acid produced in an oxidation ditch from waste. Conf. Process and Managem. of Agric. Waste, Cornell 1974, 375-381.

Loehr, R. C.: Environmental Sciences. Agricultural Waste Management. Problems, Processes and Approaches. New York and London 1974, p. 538.

Madsen, A.: Protein nutrition of growing pigs. Festskr. til Hj. Clausen. Copenhagen 1975, 221-241.

Näsi, M.: Kananlannan hyödyntäminen kotieläinten rehuna ja mikrobifermentaation avulla. (The use of dried poultry manure as animal feed and by microbial fermentation). Lic. thesis, Univ. of Helsinki 1976, $112 \mathrm{pp}$.

Partanen, J.: Lihasikojen uudet viikottaiset ry-normit. (Weekly feed unit standards for growing pigs). Sika 1970, 205, 6-17.

Perez-Aleman, S., D. G. Dempster, P. R. English \& J. H. Topps: A note on dried poultry manure in the diet of the growing pig. Anim. Prod. 1971, 13, 361-364.

Uusisalmi, U.: Vorläufige Ergebnisse über das Messen der Schlachteigenschaften beim Schwein. (Measurements of carcase characteristics of pigs). J. sci. agric. Soc. Finl. 1969, 41, 50-58.

\section{SAMMANFATTNING}

Torkad minkgödsel som proteinkälla àt gödsvin.

Användningen av torkad minkgödsel som proteinkälla åt gödsvin undersöktes genom att ersätta 7,5 respektive $15 \%(\mathrm{w} / \mathrm{w})$ av helfoderblandningen med minkgödsel och motsvarande mängd korn. I jämförelse med tidigare utförda smältbarhetsförsök med minkar, hade den använda gödseln lågt fodervärde. Råproteinhalten var 21,3\%. Någon negativ inverkan på svinens foderkonsumption eller hälsotillstånd kunde inte konstateras i samband med minkgödselutfodringen. Statistiskt signifikanta skillnader $i$ vikt och foderutbyte kunde inte iakttagas. Försöksdjurens antal var litet, och stora variationer förekom inom försöksgrupperna. Minkgödseltillsatsen resulterade $i$ långsammare tillväxt, uppenbarligen till följd av lägre energitillförsel. De för- 
söksgrupper som fick av gödseln erhöll ett lägre antal foderenheter än kontrolldjuren. Vid organoleptisk undersökning av slaktkropparna kunde inga negativa förändringar med avseende å lukt eller smak på köttet konstateras. Svinens matsmältningskanal, lever och njurar uppvisade heller inga förändringar.

(Received September 5, 1977).

Reprints may be requested from: Matti Näsi, the Department of Animal Husbandry, University of Helsinki, 00710 Helsinki 71, Finland. 